\section{Characterizing the Interaction between NAA and BA on Apple Fruit Abscission and Development}

\author{
Martin J. Bukovac ${ }^{1}$ and Paolo Sabbatini \\ Department of Horticulture, Michigan State University, 390 PSSB, East \\ Lansing, MI 48824-1525
}

Philip G. Schwallier

Clarksville Horticultural Experiment Station, Michigan State University, 9302 Portland Road, Clarksville, MI 48815

\section{Michael Schroeder \\ Kompetenzzentrum Obstbau-Bodensee, Ravensburg, Germany 82213}

Additional index words. fruit thinning, fruit growth, pygmy fruit, Maxcel, Accel, Promalin, Malus domestica

\begin{abstract}
NAA and BA are important compounds for regulating crop load in apples (Malus domestica Borkh.). When used for fruit thinning, both induce abscission, but at an equivalent crop load NAA tends to reduce and BA to increase fruit size. There is a strong interaction between NAA and BA when used together on 'Delicious' and 'Fuji', leading to excessive development of pygmy and small fruit $(<65 \mathrm{~mm}$ diameter). The combination of BA (as Promalin, 1:1 BA + $\mathbf{G A}_{4+7}$ ) applied at king bloom (KB) and NAAm (amide) at petal fall increased the percentage of small fruit by 3.3- or 5.1-fold compared with BA or NAAm alone. Similar results were obtained with BA (Promalin) at KB oversprayed with NAA at 10 to $12 \mathrm{~mm}$ king fruit diameter (KFD). When NAA was oversprayed with BA during fruitlet development, i.e., 5 to $6 \mathrm{~mm}, 10$ to $12 \mathrm{~mm}$, and $\approx 18 \mathrm{~mm}$ KFD, the greatest inhibition of fruit growth occurred at the 10- to 12-mm KFD stage, and there was no significant effect at $18 \mathrm{~mm}$ KFD. Inhibition by treatment at the 5- to 6-mm stage was intermediate and trees were overthinned. NAA + BA inhibition of fruit growth in 'Delicious' and 'Fuji' was not crop load-dependent. In all experiments, crop load (wt basis) of trees treated with NAA + BA was similar or less than of those treated with NAA or BA alone, but they produced 2.5- to 5-fold more small fruit. NAA + BA increased the number of fruit per cluster, many of which failed to fully develop. Increasing the ratio of BA to NAA from 25:15 to $125: 15 \mathrm{mg} \cdot \mathrm{L}^{-1}$ increased small fruit formation. The presence of $\mathrm{GA}_{4+7}$ in commercial formulations of BA (0:100, Maxcel; 10:100, Accel; 50:50, Promalin) did not significantly affect the NAA + BA response. Fruit growth was not inhibited by the NAA + BA combination in large-fruited 'Golden Delicious' and 'Jonagold' and was increased in small-fruited 'Elstar' and 'Gala' compared with the nontreated control.
\end{abstract}

The discovery of auxins provided the basis for current chemical fruit thinning of apples. The promotion of postbloom fruit abscission was first reported over 60 years ago (Davidson et al., 1945), and since then, synthetic auxins, NAA and its amide (NAAm), have become dominant apple fruit-thinning compounds (Dennis, 2000). Numerous studies have documented their effectiveness for fruit thinning, but their performance has been inconsistent and is subject to environmental conditions, particularly temperature and relative humidity during and for a short period after application (Luckwill and Lloyd-Jones, 1962; Wertheim, 2000; Westwood and Batjer, 1960; Williams, 1979).

Also, NAA has been reported to cause a transitory depression in the rate of fruit growth for a brief period after treatment and thus, the increase in size of the persisting fruit

Received for publication 18 Apr. 2008. Accepted for publication 10 June 2008 .

${ }^{1}$ To whom reprint requests should be addressed; e-mail bukovacm@msu.edu et al., 2001), promoted enlargement of the cortical tissue in the calyx lobes in 'Delicious', and increased cell division in apple and pear fruit (Flaishman et al., 2005; Greenhalgh et al., 1977; Letham, 1968; Williams and Stahly, 1960). Numerous thinning studies have confirmed that cytokinins induce fruit abscission and increase fruit size in apple and pear and that the fruit size is often greater than can be accounted for by the thinning effect (Bukovac et al., 2000; Flaishman et al., 2005; Greene et al., 1992; Wismer et al., 1995), thus suggesting a direct, positive effect on fruit growth.

In attempts to improve fruit thinning in hard-to-thin cultivars, combinations of chemicals have been used for aggressive thinning (Wertheim, 2000). An early, perhaps first, study using NAA and BA on 'Delicious' identified a strong interaction leading to excessive production of pygmy fruit (Miller, 1985). We observed a similar increase, not only in pygmy fruit, but also in the population of small fruit $(<65 \mathrm{~mm})$ in a grower study when NAA was used at $\approx 8 \mathrm{~mm}$ king fruit diameter (KFD) to thin 'Delicious' that were previously treated with Promalin at $80 \%$ king bloom (KB) to improve fruit typiness (E. Wittenbach, unpublished data). This response was similar, but of a greater magnitude, to that obtained with late or high concentrations of NAA (Hoffman, et al., 1955; Williams, 1979). This observation has been confirmed (Bound et al., 1991) and effects on pygmy and small fruit in 'Delicious' have been observed also when both chemicals were used for postbloom thinning on the same trees in the same season (Bukovac et al., 1995; Greene and Autio, 1994). In contrast, no significant negative cytokinin + NAA interaction has been observed on fruit growth in several other cultivars (Basak, 2006; Bukovac et al., 1995; Dennis, 2000; Stopar and Lokar, 2003).

Interactions between auxins and cytokinins on growth and differentiation are well established. Skoog and Miller (1957) demonstrated that the ratio (and concentration) of cytokinin to auxin in the culture media had a dramatic effect on organogenesis of cultured, undifferentiated tobacco tissue. In the presence of low auxin level $(\approx 2$ $\mathrm{mg} \cdot \mathrm{L}^{-1}$ ), increasing the cytokinin concentration $\left(\approx 0.02\right.$ to $\left.10 \mathrm{mg} \cdot \mathrm{L}^{-1}\right)$ induced root formation. On increasing the auxin:cytokinin ratio further, the tissue went through a rapid undifferentiated, proliferation stage and then developed buds. A high cytokinin:auxin ratio resulted in an undifferentiated callus and growth was inhibited. This interaction between auxins and cytokinins has been demonstrated for numerous plant tissues and, once the culture medium is optimized, provides the basis for regeneration and micropropagation of plants. Such findings have led to the suggestion that the ratio of these two hormones plays a defining role in controlling differentiation and growth in intact plants. Both auxins and cytokinins are present in apple fruitlets (Letham and Williams, 1969; Luckwill, 1953). However, the role of neither 
endogenous nor exogenous cytokinins in apple fruit development is understood.

The objective of our study was to provide a better understanding of this interaction by characterizing how the addition of BA modifies the effect of NAA on apple fruit abscission and development.

\section{Materials and Methods}

General. Studies were conducted at the Clarksville Horticultural Experiment Station on mature (10- to 14-year-old) trees of moderate vigor and receiving recommended horticultural and crop protection practices. Irrigation (trickle) was provided as needed. The designated chemicals were applied with a hand gun as a high-volume, foliar spray (2.4 $\mathrm{MPa})$ to single trees, selected for uniformity of bloom density, replicated four to 10 times in random complete block designs. The effect on fruit abscission was indexed in all experiments by measuring yield per tree and fruit size ('Delicious' and 'Empire') by grading the fruit (per tree basis) into seven size classes $(<51,51$ to 56,57 to 64,65 to 69 , 70 to 75,76 to $82,>82 \mathrm{~mm}$ diameter) using a Greefa Grader, Tricht-Geldermalen, Holland. In addition, the number of fruit per tree in Expt. 2 and Expt. 3 was estimated by dividing the total weight of fruit in each size class by the appropriate mean weight of a 100-fruit sample. For the other cultivars (Fuji, Elstar, Gala, Golden Delicious, Jonagold), all fruit was harvested on a per-tree basis and individual fruit were counted and weighed (Compac-Computerized Grading System, Auckland, New Zealand). The raw data were then sorted and assigned to designated size classes. Basic statistics was performed on all data. When appropriate, data were also subjected to analysis of variance or regression analysis using SAS (SAS Institute, Cary, NC) or Sigma Plot (SPSS, Chicago).

Chemicals and abbreviations. The following chemicals were used: BA formulated as Promalin $\left(1.8 \% \mathrm{BA}+1.8 \% \mathrm{GA}_{4+7}\right)$, $\mathrm{BA}$ formulated as Accel $(1.8 \% \mathrm{BA}+0.18 \%$ $\left.\mathrm{GA}_{4+7}\right)$, BA formulated as Maxcel $(1.9 \%$ BA) from Abbott Laboratories, now Valent Biosciences Corp. (Libertyville, I1l), NAAm (Amid-Thin W, 8.4\%, 1-naphthaleneacetamide), and NAA (Fruitone N, 3.5\%, 1-naphthaleneacetic acid as the sodium salt) from AMVAC Chemical Corp. (Los Angeles, CA). No spray additives were used. The time of treatment was based on flower and fruit development, $80 \% \mathrm{~KB}$ and designated mean diameter of the king fruitlet (KF). A nonthinned control (NTC) and/or hand-thinned control (HT) was included for comparison. HT was performed during or immediately after June drop ( $\approx 25 \mathrm{~mm}$ fruit diameter).

We found no significant differences between the effects of the Maxcel and Accel formulations of BA in these studies and in a direct comparison on thinning (M.J. Bukovac, unpublished data). Therefore, we identify the formulations used for each experiment but refer to both as BA in the "Results" and "Discussion".

Table 1. Effects of Promalin and NAAm, applied alone and Promalin oversprayed with NAAm, on total yield and yield in fruit diameter size classes of less than $65 \mathrm{~mm}$ and greater than $70 \mathrm{~mm}$ in Redchief 'Delicious' apple.

\begin{tabular}{lccccccc}
\hline & \multicolumn{2}{c}{ Yield $^{\mathrm{z}}$} & & \multicolumn{3}{c}{ Fruit size class $(\mathrm{kg})^{\mathrm{z}}$} \\
\cline { 2 - 3 } \cline { 5 - 7 } Treatment & $\mathrm{kg} /$ tree & $\mathrm{NTC}^{\mathrm{x}}(\%)$ & & $<65 \mathrm{~mm}$ & $\mathrm{NTC}(\%)$ & $>70 \mathrm{~mm}$ & NTC $^{\mathrm{x}}(\%)$ \\
\hline NTC & $125 \mathrm{a}$ & 100 & & $23 \mathrm{ab}$ & 100 & $33 \mathrm{~b}$ & 100 \\
Promalin & $106 \mathrm{ab}$ & 85 & & $11 \mathrm{~b}$ & 48 & $64 \mathrm{ab}$ & 194 \\
NAAm & $85 \mathrm{~b}$ & 68 & & $7 \mathrm{~b}$ & 30 & $78 \mathrm{a}$ & 236 \\
Promalin + NAAm & $84 \mathrm{~b}$ & 67 & & $36 \mathrm{a}$ & 157 & $59 \mathrm{ab}$ & 179 \\
\hline
\end{tabular}

${ }^{2}$ Means within a column followed by the same letters are not significantly different $(P=0.05)$ by the Tukey's honestly significant difference test.

yPromalin $\left(35 \mathrm{mg} \cdot \mathrm{L}^{-1}\right)$ applied at $80 \%$ king bloom and NAAm $\left(50 \mathrm{mg} \cdot \mathrm{L}^{-1}\right)$ at $80 \%$ petal fall as highvolume sprays.

${ }^{\mathrm{x}} \mathrm{NTC}=$ nontreated control

Table 2. Effects of Promalin applied at king bloom (KB) and oversprayed with NAA at KB or at king fruit diameters $(\mathrm{KF})$ of $\approx 10 \mathrm{~mm}$ and $\approx 18 \mathrm{~mm}$ on total yield and yield in fruit diameter size classes less than $65 \mathrm{~mm}$ and greater than $70 \mathrm{~mm}$ in Redchief 'Delicious' apple.

\begin{tabular}{|c|c|c|c|c|c|c|c|}
\hline \multirow[b]{2}{*}{ Treatment ${ }^{y}$} & \multicolumn{3}{|c|}{ Yield $^{2}$} & \multicolumn{4}{|c|}{ Fruit size class $(\mathrm{kg})^{\mathrm{z}}$} \\
\hline & $\mathrm{kg} /$ tree & $\begin{array}{l}\text { Percent } \\
\text { thinned }\end{array}$ & $\begin{array}{l}\text { Calculated fruit } \\
\text { (no./tree })^{\mathrm{x}}\end{array}$ & $<65 \mathrm{~mm}$ & $\begin{array}{l}\text { NTC } \\
(\%)^{\mathrm{w}}\end{array}$ & $>70 \mathrm{~mm}$ & $\begin{array}{l}\text { NTC } \\
(\%)^{\mathrm{w}}\end{array}$ \\
\hline $\mathrm{NTC}^{\mathrm{w}}$ & $88 \mathrm{a}$ & 0 & 600 & $6.7 \mathrm{ab}$ & 100 & $80 \mathrm{bc}$ & $\overline{100}$ \\
\hline $\mathrm{HT}^{\mathrm{w}}$ & $81 \mathrm{a}$ & 8 & 489 & $1.6 \mathrm{a}$ & 24 & $92 \mathrm{ab}$ & 115 \\
\hline Promalin $_{\mathrm{KB}}(\mathrm{P})$ & $85 \mathrm{a}$ & 3 & 612 & $9.9 \mathrm{bc}$ & 148 & $73 \mathrm{~cd}$ & 91 \\
\hline $\mathrm{NAA}_{\mathrm{KF}} 10 \mathrm{~mm}$ & $66 \mathrm{a}$ & 25 & 420 & $4.9 \mathrm{ab}$ & 73 & $88 \mathrm{abc}$ & 110 \\
\hline $\mathrm{P}+\mathrm{NAA}_{\mathrm{KB}}$ & $27 \mathrm{~b}$ & 69 & 145 & $1.8 \mathrm{a}$ & 27 & $95 \mathrm{a}$ & 119 \\
\hline $\mathrm{P}+\mathrm{NAA}_{\mathrm{KF} 10 \mathrm{~mm}}$ & $58 \mathrm{ab}$ & 34 & 559 & $25.0 \mathrm{c}$ & 373 & $54 \mathrm{~d}$ & 68 \\
\hline $\mathrm{P}+\mathrm{NAA}_{\mathrm{KF} 18 \mathrm{~mm}}$ & $84 \mathrm{a}$ & 5 & 638 & $10.0 \mathrm{c}$ & 149 & $69 \mathrm{~cd}$ & 86 \\
\hline
\end{tabular}

${ }^{2}$ Means within a column followed by the same letters are not significantly different $(P=0.05)$ by Tukey's honestly significant difference test.

yPromalin $\left(35 \mathrm{mg} \cdot \mathrm{L}^{-1}\right)$ applied at $80 \% \mathrm{~KB}$ and NAA $\left(15 \mathrm{mg} \cdot \mathrm{L}^{-1}\right)$ as high-volume sprays.

${ }^{\mathrm{x}}$ See text for calculation.

wNC $=$ nontreated control; HT $=$ hand-thinned.

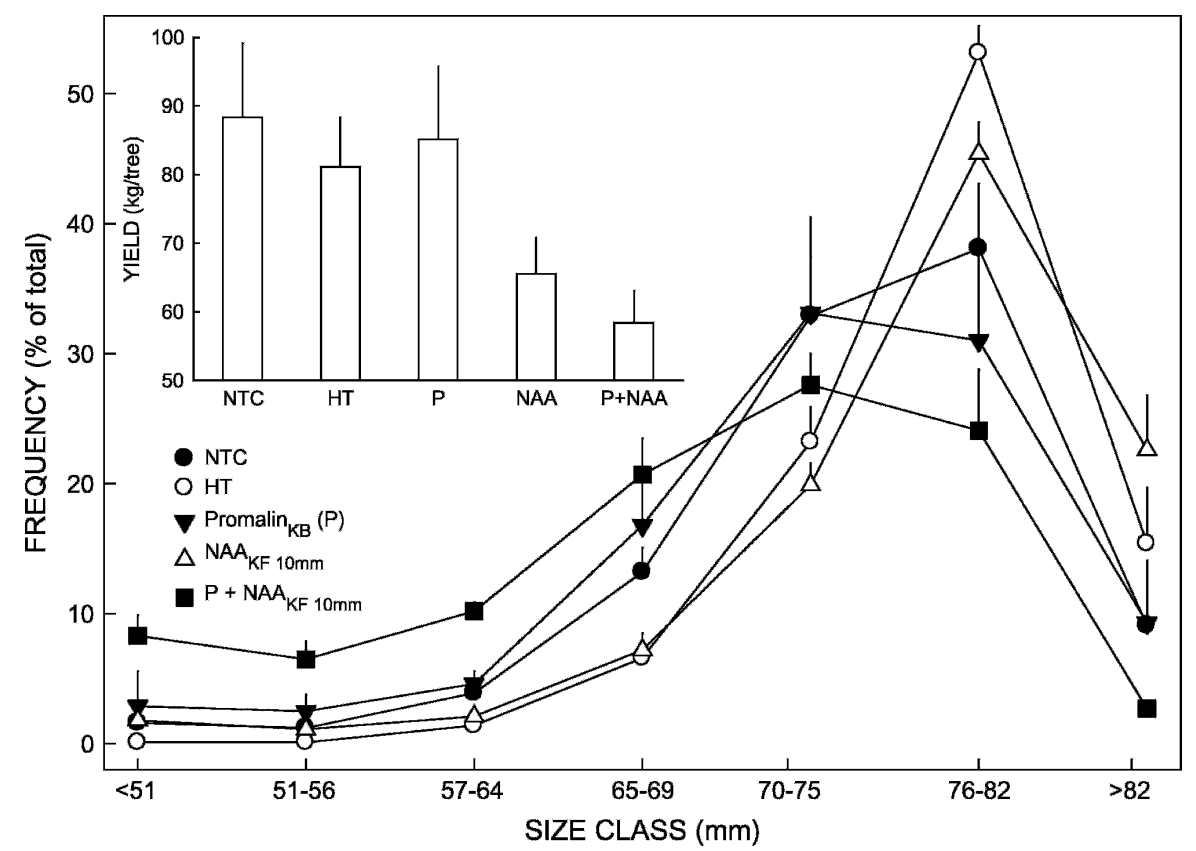

Fig. 1. Fruit size distribution profiles at harvest of Redchief 'Delicious' treated with Promalin $\left(35 \mathrm{mg} \cdot \mathrm{L}^{-1}\right)$ at $80 \%$ king bloom (KB), NAA (15 mg. $\left.\mathrm{L}^{-1}\right)$ at $10 \mathrm{~mm}$ king fruit diameter (KFD), and Promalin (KB) oversprayed with NAA (10 mm KFD) compared with nontreated (NTC) and hand-thinned (HT) controls. Yield data in inset. Bars $=\mathrm{sE}$.

Expt. 1: Promalin oversprayed with NAAm. We evaluated the effect of NAAm on fruit growth and abscission of Redchief 'Delicious'/MM.111 (13 years old) previously treated with Promalin at KB to enhance fruit form. Four single-tree treatments, replicated four times, were established: 1) NTC;
2) Promalin ( $\left.35 \mathrm{mg} \cdot \mathrm{L}^{-1}\right)$ at $\left.\mathrm{KB} ; 3\right)$ NAAm $(50$ $\left.\mathrm{mg} \cdot \mathrm{L}^{-1}\right)$ at PF; and 4) Promalin $\left(35 \mathrm{mg} \cdot \mathrm{L}^{-1}\right)$ at $\mathrm{KB}$ followed by NAAm $\left(50 \mathrm{mg} \cdot \mathrm{L}^{-1}\right)$ at postbloom (PF). Other experimental conditions were as noted in general methods.

Expt. 2: Promalin oversprayed with NAA. A similar study was performed using Redchief 
'Delicious'/M.106. (14 years old) the next season to evaluate the interaction of NAA with Promalin when NAA was oversprayed on Promalin $(\mathrm{KB})$ at different stages of flower/ fruitlet development $\left(\mathrm{KB} \rightarrow \mathrm{KFD}_{18 \mathrm{~mm}}\right)$. This increased the time between applications of the two compounds and bracketed the most active phase of cell division in the cortex of the apple fruit. Promalin $\left(35 \mathrm{mg} \cdot \mathrm{L}^{-1}\right)$ was applied at KB. NAA (15 $\left.\mathrm{mg} \cdot \mathrm{L}^{-1}\right)$ was applied alone $\left(\mathrm{KFD}_{10 \mathrm{~mm}}\right)$ and to previously Promalin $\left(35 \mathrm{mg} \cdot \mathrm{L}^{-1}\right)$-treated trees at $\mathrm{KB}$, KFD of $10 \mathrm{~mm}$ and $18 \mathrm{~mm}$. A NTC and a HT control were included. Five single-tree replications were used. Other experimental conditions were as described under general methods.

Expt. 3: Time relationship between NAA and BA application - 'Delicious'. The effect of applying both NAA and BA at the same stage of fruitlet development, and NAA before or after BA at different fruitlet developmental stages, during or after the active cell division period, was determined using Redchief 'Delicious'/M.106. NAA (15 $\left.\mathrm{mg} \cdot \mathrm{L}^{-1}\right)$ was oversprayed with BA (50 $\mathrm{mg} \cdot \mathrm{L}^{-1}$; Accel), on the same day, at fruitlet stages of $\approx 6,12$, and $18 \mathrm{~mm} \mathrm{KFD.} \mathrm{For}$ the two treatments in which NAA and BA were applied at different stages ( $6 \mathrm{~mm}$ versus $12 \mathrm{~mm} \mathrm{KFD}$ ), the NAA and BA treatments were applied at $6 \mathrm{~mm} \mathrm{KFD}$, and the NAAtreated trees were oversprayed with $\mathrm{BA}$ and the BA-treated trees with NAA at $12 \mathrm{~mm}$ KFD. Each single tree treatment was replicated four times. Other experimental parameters were as described in the general methods.

Expt. 4: Time relationship between NAA and BA application - 'Fuji'. A similar study on effect of time of NAA versus BA application on fruit growth and abscission was conducted on 6-year-old Myrared 'Fuji'/ G.30. NAA (15 mg. $\left.\mathrm{L}^{-1}\right)$ and BA $\left(125 \mathrm{mg} \cdot \mathrm{L}^{-1}\right.$; Maxcel) were applied both as independent treatments and together (NAA oversprayed with BA on the same day at $12 \mathrm{~mm} \mathrm{KFD).}$ Two additional combination treatments were established: NAA $\left(15 \mathrm{mg} \cdot \mathrm{L}^{-1}, 6 \mathrm{~mm} \mathrm{KFD}\right)$ was oversprayed with BA $\left(125 \mathrm{mg} \cdot \mathrm{L}^{-1}, 12\right.$ $\mathrm{mm}$ KFD) and BA (125 mg. $\mathrm{L}^{-1}, 6 \mathrm{~mm}$ KFD) was oversprayed with NAA $\left(15 \mathrm{mg} \cdot \mathrm{L}^{-1}, 12\right.$ mm KFD). A NTC was used for comparative purposes. Each single tree treatment was replicated 10 times. Treatment effects on abscission were indexed by yield and number of fruit per tree and on size by individual fruit weight/diameter at harvest. Other experimental parameters were as described in the general section.

Expt. 5: BA:NAA ratio. 'Delicious'/MM. 111 and 'Empire'/M.106 were selected to establish the effect of an increasing ratio of $\mathrm{BA}$ to NAA on the NAA effect on fruit growth and abscission. 'Delicious' was selected because of the marked inhibition of $\mathrm{NAA}+\mathrm{BA}$ on fruit growth and 'Empire' because, in an earlier study (Bukovac et al., 1995), this combination had no effect or increased fruit size. This evaluation was performed as two separate experiments in

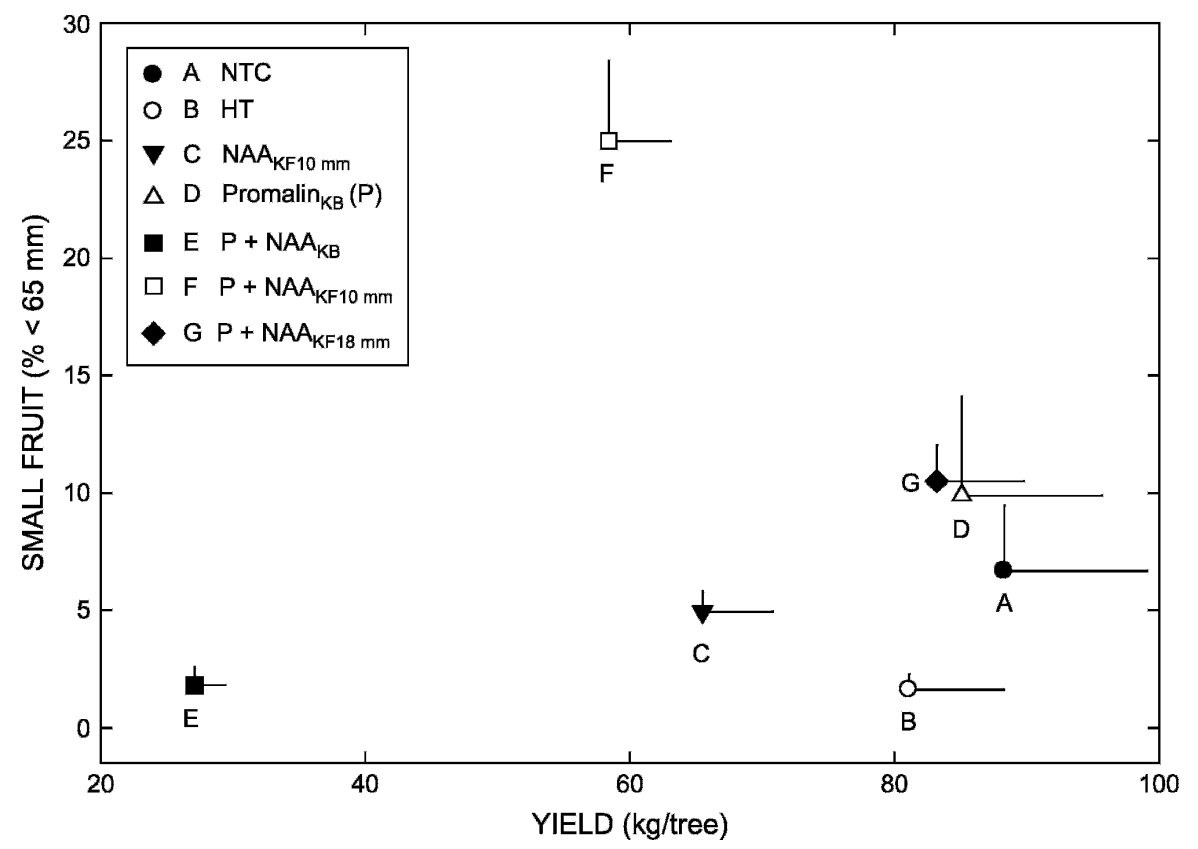

Fig. 2. Relationship between percentage of small fruit and yield in Redchief 'Delicious' treated with Promalin $\left(\mathrm{P}, 35 \mathrm{mg} \cdot \mathrm{L}^{-1}\right)$ at $80 \%$ king bloom $(\mathrm{KB})$ and oversprayed with NAA $\left(15 \mathrm{mg} \cdot \mathrm{L}^{-1}\right)$ at $\mathrm{KB}, 10$ $\mathrm{mm}$ or $18 \mathrm{~mm}$ king fruit diameter (KFD) compared with Promalin $(\mathrm{P})$ at KB alone, NAA $(10 \mathrm{~mm}$, $\mathrm{KFD}$ ) alone and nontreated (NTC) and hand-thinned (HT) controls. Bars = SE.

the same orchard and in the same year. In the 'Delicious' study, treatments consisted of $\mathrm{NAA}$ at 0 and $15 \mathrm{mg} \cdot \mathrm{L}^{-1}$, and NAA (15 $\left.\mathrm{mg} \cdot \mathrm{L}^{-1}\right)$ in combination with $0,25,50$, and $100 \mathrm{mg} \cdot \mathrm{L}^{-1} \mathrm{BA}$ (Accel). NAA was applied at 8 to $10 \mathrm{~mm}$ KFD and the trees were oversprayed with BA 2 to $4 \mathrm{~h}$ after the NAA spray application dried. Each single tree treatment was replicated four times. In the 'Empire' study, treatments consisted of NAA at 0 and $15 \mathrm{mg} \cdot \mathrm{L}^{-1}$ alone and in combination (oversprayed) with BA at 0,25 , and $50 \mathrm{mg} \cdot \mathrm{L}^{-1}$. Other experimental factors were as described for 'Delicious' previously. The amount of small fruit produced was used as an index for the effect on fruit growth.

Expt. 6: Cultivar comparison. The effects of NAA and BA alone and NAA oversprayed with BA (on the same day) were evaluated on two small-fruited ('Elstar'/M.9 and Imperial 'Gala'/Bud 9) and two large-fruited (Smoothee 'Golden Delicious'/G.30 and 'Jonagold'/ G.30) cultivars. Concentration and stage of fruit development were as follow:) 'Elstar'-NAA (15 mg. $\left.\mathrm{L}^{-1}\right), \mathrm{BA}\left(50 \mathrm{mg} \cdot \mathrm{L}^{-1}\right)$, and NAA + BA (same concentrations) at 7 mm KFD; 2) 'Gala'-NAA (15 mg. $\left.\mathrm{L}^{-1}\right) \mathrm{BA}$ $\left(100 \mathrm{mg} \cdot \mathrm{L}^{-1}\right)$, and NAA $\left(10 \mathrm{mg} \cdot \mathrm{L}^{-1}\right)+\mathrm{BA}$ $\left(100 \mathrm{mg} \cdot \mathrm{L}^{-1}\right)$ at $9 \mathrm{~mm} \mathrm{KFD}$; 3$)$ 'Golden Delicious'-NAA (15 mg. $\left.\mathrm{L}^{-1}\right)$, BA (125 $\mathrm{mg} \cdot \mathrm{L}^{-1}$ ), and NAA + BA (same concentrations) at $13 \mathrm{~mm} \mathrm{KFD}$; and 4) 'Jonagold'NAA $\left(10 \mathrm{mg} \cdot \mathrm{L}^{-1}\right)$, BA $\left(75 \mathrm{mg} \cdot \mathrm{L}^{-1}\right)$, and $\mathrm{NAA}+\mathrm{BA}$ (same concentrations) at $11 \mathrm{~mm}$ KFD. Each treatment was applied to 10 trees in a randomized complete block design. Treatment effects were assessed by total yield, size, and number (data not presented) of fruit per tree. Other experimental factors were as described earlier.

\section{Results}

Expt. 1: Promalin oversprayed with NAAm. Promalin applied at $\mathrm{KB}$ had no significant effect on fruit abscission as indexed by yield per tree (Table 1). NAAm reduced yield $(\approx 32 \%)$, and the effect of NAAm was not altered by the KB Promalin treatment. The yield of small fruit $(<65 \mathrm{~mm})$ was reduced by $\approx 52 \%$ and $70 \%$ by Promalin and NAAm, respectively, compared with the NTC (Table 1). However, the combination of Promalin and NAAm increased the percentage of small fruit by 3.3-fold and 5.1-fold compared with Promalin and NAAm alone, respectively. The percentage of large $(>70$ $\mathrm{mm}$ ) fruit was increased significantly by NAAm, but not significantly greater than Promalin or NAAm plus Promalin (Table 1).

Expt. 2: Promalin oversprayed with NAA. Fruit size profiles for NTC, HT, and NAA only treatments were similar, all having the greatest amount of fruit in the 76- to $82-\mathrm{mm}$ size class (Fig. 1). Fruit from the Promalintreated trees had a similar profile, but the greatest amount of fruit was shifted to the next smaller class, i.e., 70 to $75 \mathrm{~mm}$. The fruit size distribution curve for the NAA (KFD $10 \mathrm{~mm}$ ) treatment after Promalin (KB) was skewed to smaller size classes with consistently more fruit in the less than $51 \mathrm{~mm}$ to $70-\mathrm{mm}$ classes and less in the two largest classes (76 to 82 $\mathrm{mm},>82 \mathrm{~mm}$ ) than in all other treatments and intermediate in the 70 - to $75-\mathrm{mm}$ class.

Promalin alone had no effect on yield (Table 2). Although NAA appeared to reduce yield by $\approx 25 \%$, the effect was not significantly different from the NTC. NAA oversprayed on Promalin at KB, or KFD of $10 \mathrm{~mm}$ and $18 \mathrm{~mm}$, thinned fruit, as indexed by yield, 
by $\approx 69 \%, 34 \%$, and $5 \%$, respectively, but only the Promalin $+\mathrm{NAA}_{\mathrm{KB}}$ treatment differed significantly from NTC (Table 2). The thinning response based on calculated number of fruit per tree closely followed the treatment effects indexed by weight.

Compared with the NTC, neither Promalin nor NAA alone had a significant effect on percentage of small $(<65 \mathrm{~mm})$ fruit produced. When Promalin-treated trees were oversprayed with NAA at KB, they were overthinned and the percentage of small fruit was reduced to $27 \%$. However, overspraying Promalin with NAA at $10 \mathrm{~mm}$ KFD increased the percentage of small fruit by 3.7-fold, and application at KFD of $18 \mathrm{~mm}$ increased the percentage by 1.5-fold compared with the NTC; the latter equaled Promalin alone. Promalin plus NAA applied at KFD of $10 \mathrm{~mm}$ reduced crop load by $31 \%$ relative to Promalin plus NAA at 18 $\mathrm{mm}$, but increased the percentage of small fruit 2.5 -fold. Thus, the effect of the combination on inducing small fruit differed markedly with stage of flower/fruit development. Furthermore, Promalin + NAA at $10 \mathrm{~mm}$ KFD decreased crop load by $34 \%$ compared with the NTC but increased the percentage of small fruit by 3.7 -fold. Thus, the Promalin + NAA effect on small fruit formation was not related to crop load (Table 2; Fig. 2).

Expt. 3: Time relationship between NAA and BA application - 'Delicious'. The effects of BA and NAA on fruit abscission and growth were related not only to the stage of fruitlet development at time of treatment, but also to the sequence of their application (Table 3; Fig. 3). When BA was oversprayed on NAA on the same day (same developmental stage) during early fruitlet development (6 to $18 \mathrm{~mm}$ KFD), the thinning response, compared with NTC, was greatest at $6 \mathrm{~mm}$ KFD and then decreased with fruit development (Table 3). The response at $18 \mathrm{~mm} \mathrm{KFD}$ was almost the same as for the NTC. Application of NAA (6 mm KFD) before BA (12 mm KFD) was more effective than applying BA (6 mm KFD) before NAA (12 mm KFD). Similar treatment effects on thinning were apparent based on calculated number of fruit per tree.

Fruit size profiles document distinctly different effects of NAA + BA on fruit growth depending on time and sequence of treatment (Fig. 3). When both compounds were applied to 'Delicious', the profiles for $\mathrm{NAA}+\mathrm{BA}$ at $18 \mathrm{~mm}$ KFD and the NTC were identical (Fig. 3A). When applied at $6 \mathrm{~mm}$ $\mathrm{KFD}$, the profile was skewed to larger fruit, but $\approx 23 \%$ of the total population was still less than $65 \mathrm{~mm}$. The profile after treatment at $12 \mathrm{~mm}$ KFD was normally distributed; it peaked at $65-$ to $69-\mathrm{mm}$ class and tailed with shallow slopes in both directions (Fig. 3A). Overspraying NAA and BA on the same trees at two different stages of fruitlet development revealed that NAA applied early $(6 \mathrm{~mm}$ $\mathrm{KFD})$ and BA late $(12 \mathrm{~mm} \mathrm{KFD})$ resulted in more small fruit than when BA was applied early and NAA late (Fig. 3B).

Expt. 4: Time relationship between NAA and BA applications-'Fuji'. In 'Fuji', all

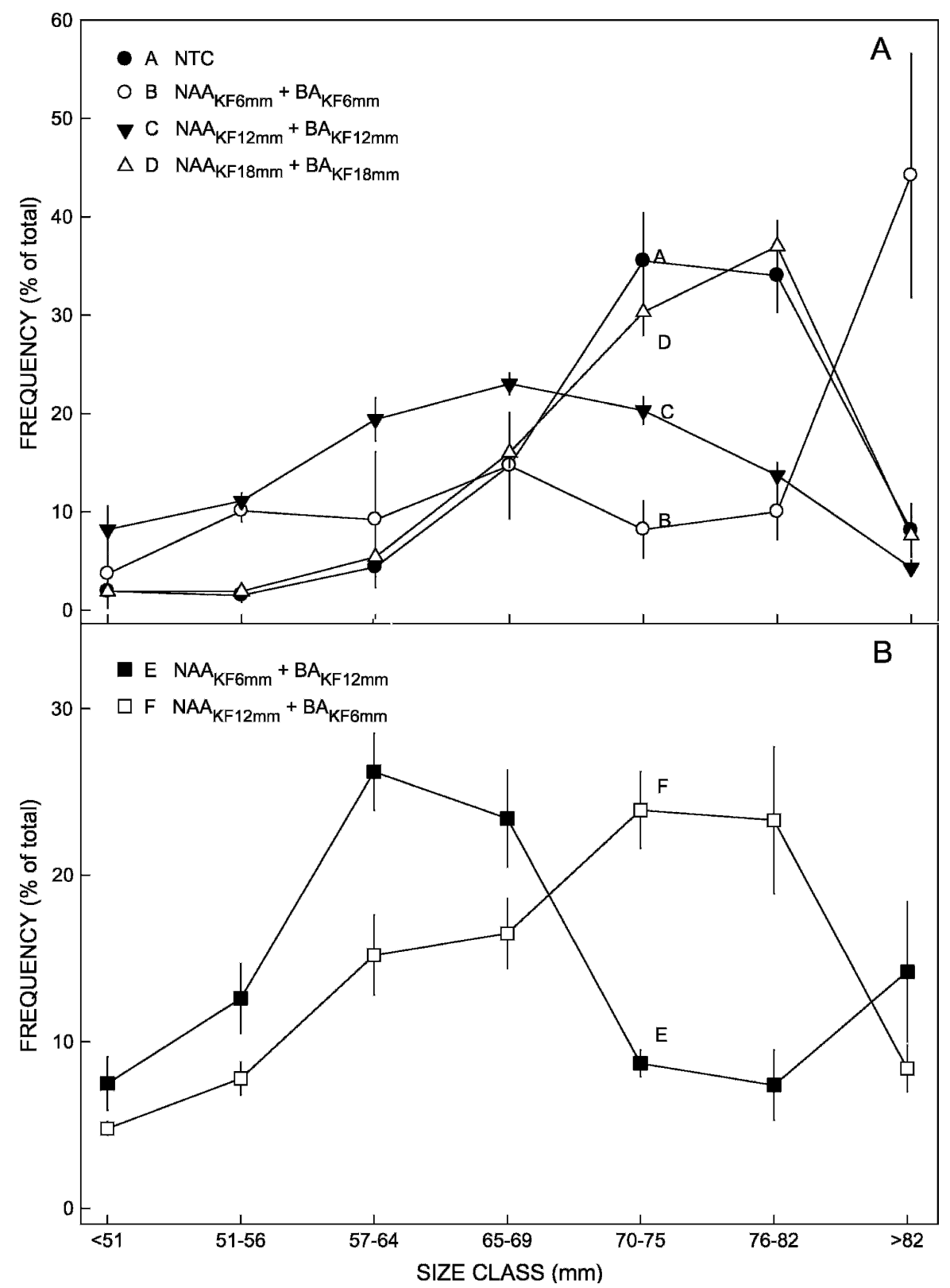

Fig. 3. Fruit size distribution profiles at harvest of Redchief 'Delicious' treated with NAA $\left(15 \mathrm{mg} \cdot \mathrm{L}^{-1}\right)$ and oversprayed with BA $\left(50 \mathrm{mg} \cdot \mathrm{L}^{-1}\right)$ at king fruit diameters (KFD) of $6 \mathrm{~mm}, 12 \mathrm{~mm}$, and $18 \mathrm{~mm}$ compared with nontreated control (A) and when NAA was applied at $6 \mathrm{~mm} \mathrm{KFD}$ followed by BA at $12 \mathrm{~mm} \mathrm{KFD}$ and the reciprocal sequence $(\mathbf{B})$. Bars $=$ SE.

Table 3. Effects of NAA and BA applied at the same or different stages of early fruitlet development on yield of Redchief 'Delicious' applez.

\begin{tabular}{|c|c|c|c|}
\hline \multirow[b]{2}{*}{ NAA/BA treatment ${ }^{x}$} & \multicolumn{3}{|c|}{ Yield $^{y}$} \\
\hline & $\mathrm{kg} /$ tree & NTC (\%) & Fruit no./tree ${ }^{\mathrm{w}}$ \\
\hline None (NTC) & $85 \mathrm{a}$ & 100 & 596 \\
\hline \multicolumn{4}{|l|}{ Both at the same KFD of } \\
\hline$\approx 6 \mathrm{~mm}$ & $5 \mathrm{~d}$ & 6 & 41 \\
\hline$\approx 12 \mathrm{~mm}$ & $67 \mathrm{bc}$ & 79 & 715 \\
\hline$\approx 18 \mathrm{~mm}$ & $81 \mathrm{ab}$ & 95 & 584 \\
\hline \multicolumn{4}{|l|}{ NAA before or after BA } \\
\hline $\mathrm{NAA}_{6 \mathrm{~mm}} / \mathrm{BA}_{12 \mathrm{~mm}}$ & $20 \mathrm{~d}$ & 24 & 218 \\
\hline $\mathrm{BA}_{6 \mathrm{~mm}} / \mathrm{NAA}_{12 \mathrm{~mm}}$ & $50 \mathrm{c}$ & 59 & 443 \\
\hline
\end{tabular}

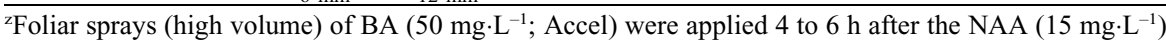
spray dried when both compounds were applied at the same stage of fruit development.

'Means followed by the same letters are not significantly different $(P=0.05)$ by the Tukey's honestly significant difference test.

${ }^{\times}$High-volume sprays were made at the noted diameters of the king fruit (KFD).

${ }^{\text {w}}$ Calculated number; see text for calculation. 
BA treatments reduced yield significantly (Table 4). NAA alone reduced yield, but not significantly. Number of fruit per tree was closely related to yield except for NAA + BA applied at $12 \mathrm{~mm} \mathrm{KFD}$, in which a large number (404/tree) of small fruit (average 105 $\mathrm{g}, \approx 30 \%$ less than the NTC) were produced. Yield and number of fruit per tree were similar for NAA + BA treatments applied at two different stages $\left(\mathrm{KF}_{6 \mathrm{~mm}}\right.$ versus $\left.\mathrm{KF}_{12 \mathrm{~mm}}\right)$, but mean fruit size was significantly less when BA was applied before, rather than after, NAA.

NAA and BA applied on the same day at $12 \mathrm{~mm}$ KFD dramatically increased the percentage of small fruit $(<75 \mathrm{~mm})$ compared with application of either alone (Fig. 4A). Similar fruit size distribution profiles were obtained whether NAA was applied before or after BA. The percentage of small fruit, based on number of fruit per tree, was $\approx 1.4$-fold greater than when expressed on a fresh weight basis (Fig. 4A versus 4B). Significantly more small fruit were present when NAA was used alone compared with BA alone. There were no significant differences between the fruit size profiles relative to the sequence of NAA/BA applications.

Expt. 5: BA:NAA ratio. The ratio of the concentration of BA to NAA had a significant effect on formation of small fruit in 'Delicious', but not in 'Empire' (Fig. 5). Increasing BA concentration ( 0 to $150 \mathrm{mg} \cdot \mathrm{L}^{-1}$ ) alone resulted in a slight linear $\left(\mathrm{Y}=0.06 \mathrm{x}+1.65, r^{2}=\right.$ $0.94)$ increase in percentage of small fruit in 'Delicious'. In contrast, in the presence of NAA $\left(15 \mathrm{mg} \cdot \mathrm{L}^{-1}\right)$, the percentage of small fruit increased linearly $\left(\mathrm{y}=0.38 \mathrm{x}+11.7, r^{2}=\right.$ 0.99 ) between 0 and $50 \mathrm{mg} \cdot \mathrm{L}^{-1} \mathrm{BA}$ and then plateaued, giving $\mathrm{Y}=10.90+0.57 \mathrm{x}-$ $0.004 \mathrm{x}^{2}$ for the 0 to $100 \mathrm{mg} \cdot \mathrm{L}^{-1}$ range. The effect of NAA plus BA on 'Delicious' small fruit formation was independent of crop load (Fig. 5, inset). Neither NAA nor BA alone or in combination significantly altered the percentage of small fruit formed in 'Empire'.

Expt. 6: Cultivar comparison. The combination of NAA + BA reduced yield by $8 \%$ to $49 \%$ compared with the NTC (Table 5). Mean fruit weight was significantly increased in all four cultivars. The percentage of total yield of small fruit $(<60 \mathrm{~mm})$ was significantly reduced in the small-fruited cultivars, Elstar and Gala, but not in the large-fruited 'Golden Delicious' and 'Jonagold' (Table 4) .

\section{Discussion}

Fruit thinning 'Delicious' trees with NAAm or NAA, previously treated with Promalin to increase typiness and size of the fruit, often increased pygmy fruit formation. Further studies established an interaction between NAA and BA that resulted in inhibition of fruit growth in 'Delicious' (Bound et al., 1991; Bukovac et al., 1995). Our data confirmed that NAA + BA increased pygmy fruit formation, but also dramatically increased the percentage of small $(<65 \mathrm{~mm})$ fruit. Furthermore, the effect on apple fruit growth was dependent on stage of fruitlet

Table 4. Effects of over-spraying NAA with BA at the same or different stages (6 mm versus $12 \mathrm{~mm}$ ) of king fruitlet diameter (KFD) on yield and mean fruit weight of 'Fuji' apple.

\begin{tabular}{|c|c|c|c|c|}
\hline \multirow{2}{*}{$\begin{array}{l}\text { Treatment and stage } \\
\text { of fruitlet development }\end{array}$} & \multicolumn{2}{|c|}{ Yield } & \multicolumn{2}{|c|}{ Mean fruit wt } \\
\hline & $\mathrm{kg} /$ tree $^{y}$ & No./tree & $\overline{\mathrm{g} / \text { fruit }^{\mathrm{y}}}$ & NTC $(\%)^{x}$ \\
\hline NTC $^{\mathrm{x}}$ & $65 \mathrm{a}$ & $437 \mathrm{a}$ & $149 \mathrm{c}$ & 100 \\
\hline $\mathrm{NAA}_{12} \mathrm{~mm}$ & $60 \mathrm{a}$ & $374 \mathrm{a}$ & $156 \mathrm{c}$ & 105 \\
\hline $\mathrm{BA}_{12 \mathrm{~mm}}$ & $36 \mathrm{~b}$ & $154 \mathrm{~b}$ & $227 \mathrm{a}$ & 152 \\
\hline $\mathrm{NAA}_{12 \mathrm{~mm}}+\mathrm{BA}_{12 \mathrm{~mm}}$ & $44 \mathrm{~b}$ & $404 \mathrm{a}$ & $105 \mathrm{~d}$ & 71 \\
\hline $\mathrm{NAA}_{6 \mathrm{~mm}}+\mathrm{BA}_{12 \mathrm{~mm}}$ & $42 \mathrm{~b}$ & $196 \mathrm{~b}$ & $215 \mathrm{a}$ & 144 \\
\hline $\mathrm{BA}_{6 \mathrm{~mm}}+\mathrm{NAA}_{12 \mathrm{~mm}}$ & $46 \mathrm{~b}$ & $239 \mathrm{~b}$ & $189 \mathrm{~b}$ & 127 \\
\hline
\end{tabular}

${ }^{2}$ For the overspray treatments at $12 \mathrm{~mm} \mathrm{KFD}$, NAA $\left(15 \mathrm{mg} \cdot \mathrm{L}^{-1}\right)$ and BA $\left(125 \mathrm{mg} \cdot \mathrm{L}^{-1}\right)$, the chemicals were applied as separate high-volume sprays on the same day at 4- to 6-h intervals.

'Means within a column followed by the same letter are not significantly different at $P=0.05$ by the Tukey's honestly significant difference test.

${ }^{\mathrm{x}} \mathrm{NTC}=$ nontreated control.

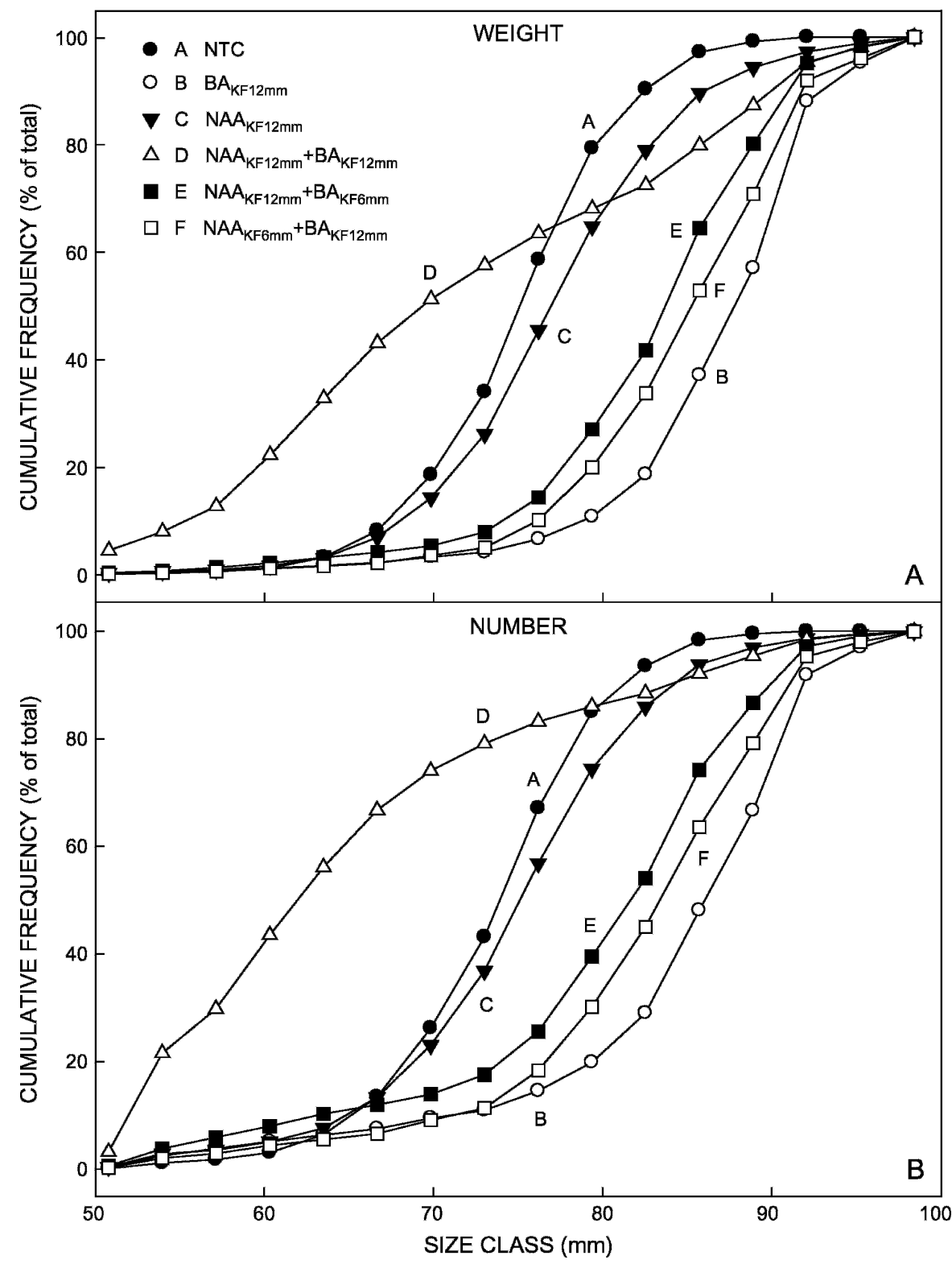

Fig. 4. Fruit size distribution profiles (cumulative frequency) at harvest of 'Fuji' from trees treated with NAA $\left(15 \mathrm{mg} \cdot \mathrm{L}^{-1}\right)$ and BA $\left(125 \mathrm{mg} \cdot \mathrm{L}^{-1}\right)$ alone and NAA oversprayed with BA at $12 \mathrm{~mm}$ king fruit diameter (KFD) compared with when NAA was applied at $6 \mathrm{~mm} \mathrm{KF}$ and oversprayed with BA at $12 \mathrm{~mm} \mathrm{KFD}$ and the reciprocal sequence and the nontreated control. Data presented as fruit weight (A) and number per tree (B).

development, the BA:NAA ratio, and cultivar and was independent of crop load and the presence of $\mathrm{GA}_{4+7}$ in the $\mathrm{BA}$ formulations (Promalin, Accel).
When NAAm was applied at PF after Promalin at $\mathrm{KB}$, the small fruit $(<65 \mathrm{~mm})$ population was increased $\approx 5$-fold compared with NAAm alone and $\approx 3$-fold greater than 


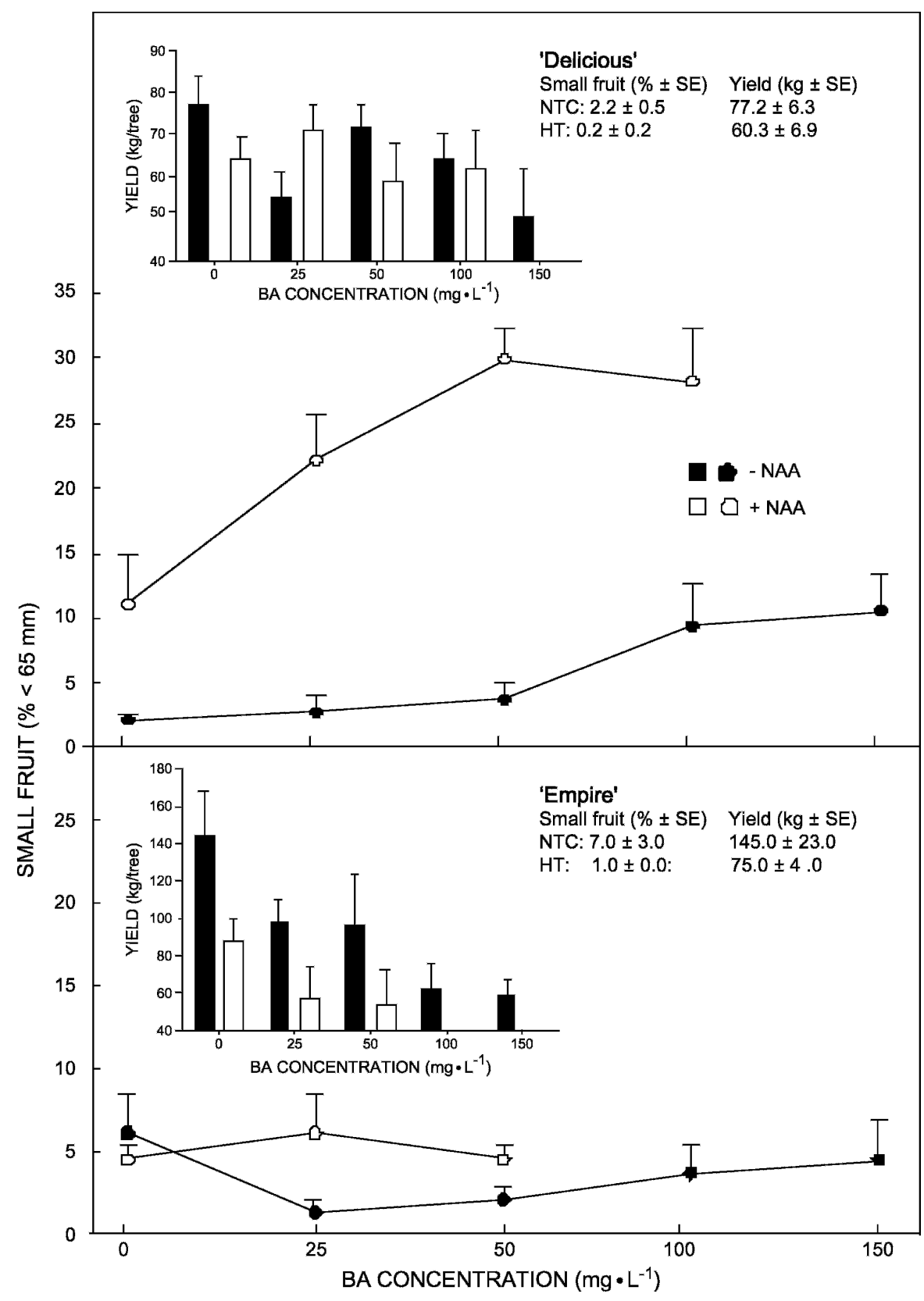

Fig. 5. Effects of increasing ratios of BA to NAA on small fruit formation and yield (inset) of 'Delicious' and 'Empire'. NAA (15 mg. $\left.\mathrm{L}^{-1}\right)$ was oversprayed with BA $\left(25\right.$ to $\left.100 \mathrm{mg} \cdot \mathrm{L}^{-1}\right)$ at 8 to $10 \mathrm{~mm} \mathrm{king} \mathrm{fruit}$ diameter. Bar graph (inset) indicates the effects of treatments on total yield per tree.

Promalin alone (Table 1). Similarly, NAA applied at $10 \mathrm{~mm}$ KFD to previously Promalin-treated (KB) 'Delicious' increased the small fruit population by 5 -fold compared with NAA alone and 2.5-fold over Promalin (Table 2). In contrast, there was a reduction in percentage of small fruit when NAA followed Promalin at KB, and there was no inhibition of fruit growth when NAA at 18 mm KFD followed Promalin (KB) compared with Promalin alone (Table 2).

Similar effects on fruit growth of 'Delicious' were observed when NAA was oversprayed with BA at 6 to $18 \mathrm{~mm}$ KFD. The greatest inhibition of fruit growth occurred when both compounds were applied at 12 $\mathrm{mm}$; no effect was apparent at $18 \mathrm{~mm}$ and an intermediate response occurred at $6 \mathrm{~mm} \mathrm{KFD}$
Table 5. Effects of overspraying NAA with BA at king fruit diameters of 10 to $12 \mathrm{~mm}$ on yield, mean fruit weight, and percentage of small fruit of two small-fruited ('Elstar', 'Gala') and two large-fruited ('Golden Delicious', 'Jonagold') cultivars.

\begin{tabular}{|c|c|c|c|}
\hline \multirow[b]{2}{*}{ Treatment $^{\mathrm{y}}$} & \multicolumn{3}{|c|}{ Measurement $^{2}$} \\
\hline & $\begin{array}{c}\text { Yield } \\
(\mathrm{kg} / \text { tree })\end{array}$ & $\begin{array}{l}\text { Mean } \\
\text { fruit wt } \\
\text { (g/fruit) }\end{array}$ & $\begin{array}{l}\text { Small fruit } \\
(\%<60 \mathrm{~mm}\end{array}$ \\
\hline \multicolumn{4}{|c|}{ Elstar $^{\mathrm{x}}$} \\
\hline $\mathrm{NTC}^{\mathrm{w}}$ & $45 \mathrm{~b}$ & $113 \mathrm{~b}$ & $11.1 \mathrm{a}$ \\
\hline $\mathrm{NAA}+\mathrm{BA}$ & $38 \mathrm{a}$ & $147 \mathrm{a}$ & $2.6 \mathrm{~b}$ \\
\hline NTC (\%) & 84 & 130 & 23 \\
\hline \multicolumn{4}{|c|}{ Gala } \\
\hline $\mathrm{NTC}^{\mathrm{w}}$ & $37 \mathrm{a}$ & $111 \mathrm{~b}$ & $2.9 \mathrm{a}$ \\
\hline $\mathrm{NAA}+\mathrm{BA}$ & $30 \mathrm{a}$ & $141 \mathrm{a}$ & $0.2 \mathrm{~b}$ \\
\hline NTC (\%) & 81 & 127 & 7 \\
\hline \multicolumn{4}{|c|}{ Golden Delicious } \\
\hline $\mathrm{NTC}^{\mathrm{w}}$ & $41 \mathrm{a}$ & $171 \mathrm{~b}$ & $1.2 \mathrm{a}$ \\
\hline $\mathrm{NAA}+\mathrm{BA}$ & $21 \mathrm{~b}$ & $207 \mathrm{a}$ & $1.2 \mathrm{a}$ \\
\hline NTC (\%) & 51 & 121 & 100 \\
\hline \multicolumn{4}{|c|}{ Jonagold } \\
\hline $\mathrm{NTC}^{\mathrm{w}}$ & $37 \mathrm{a}$ & $217 \mathrm{~b}$ & $0.4 \mathrm{a}$ \\
\hline $\mathrm{NAA}+\mathrm{BA}$ & $34 \mathrm{a}$ & $251 \mathrm{a}$ & $0.4 \mathrm{a}$ \\
\hline NTC (\%) & 92 & 116 & 100 \\
\hline
\end{tabular}

${ }^{z}$ Means within a column, within each cultivar, followed by the same letter are not significantly different at $P=0.05$ by the Tukey's honestly significant difference test.

${ }^{y}$ High-volume foliar sprays of BA applied 4 to $6 \mathrm{~h}$ after NAA spray dried. See text for rates.

'Data for 'Elstar' adapted from Bukovac et al. (2000). ${ }^{\mathrm{w}} \mathrm{NTC}=$ nontreated control.

$21 \mathrm{~mm}$ KFD (Black et al., 1995; Southwick et al., 1962). We are not aware of comparable detailed data on the effect of BA on growth rate of apple fruitlets, but BA generally results in larger fruits at harvest than NAA at similar crop loads (Elfving and Cline, 1993; Greene, 1993). Nevertheless, the NAA + BA effect in 'Delicious' appears to be closely coupled to the active cell division phase of fruit growth (Blampied and Wilde, 1968). To understand the basis of this response will require new focused research.

Data from a related study with Redchief 'Delicious' provide insight on the NAA $\times$ BA interaction on fruit growth (Black et al., 2000). We found that fruit size on a given spur was not correlated with the presence of fruit on other spurs (interspur competition) on the same branch, but was highly correlated with fruit on the same spur (intraspur competition). Analysis of the effect of fruit position and number of fruit per spur revealed that the KF or a dominate lateral fruit (LF) in the absence of a KF was consistently the largest fruit with minimal variation $(\approx 4 \%)$ in the presence of one or two LF. However, the size (wt basis) of a single LF in the presence of a KF was $\approx 20 \%$ less than the KF. If two LF were present, the secondary fruit was $\approx 10 \%$ and tertiary $\approx 28 \%$ smaller than the KF. Typical effect of BA + NAA on relative size of 'Delicious' fruit at maturity is illustrated in Figure 6.

The application of NAA and BA alone or together (oversprayed) affected the frequency of multifruited spurs (Black et al., 2000). $\mathrm{NAA}+\mathrm{BA}$ increased the frequency by $31 \%$ compared with the NTC and $\approx 73 \%$ and $\approx 56 \%$ compared with NAA and BA, respectively. 


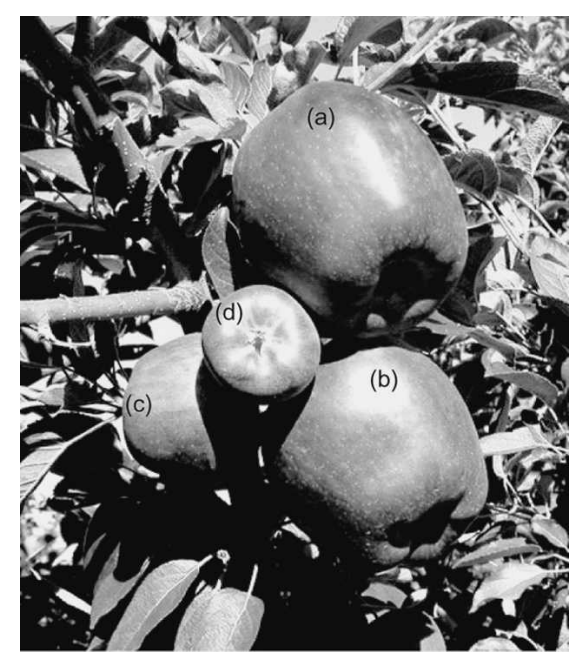

Fig. 6. Photograph of Redchief 'Delicious' fruit illustrating the difference in size of king and lateral fruit at harvest in response to a foliar spray of NAA $\left(15 \mathrm{mg} \cdot \mathrm{L}^{-1}\right)$ oversprayed with BA $\left(100 \mathrm{mg} \cdot \mathrm{L}^{-1}\right)$ at $\approx 10 \mathrm{~mm}$ king fruit diameter. King fruit only per spur (A), king fruit (B) with a secondary (C) and tertiary (D) lateral fruit per spur.

Furthermore, the growth of a KF in the presence of a single LF was not significantly inhibited by NAA + BA, but the growth of the LF was depressed by $16 \%$. Growth of a single LF per spur was not inhibited, but the size of a LF was reduced by $27 \%$, in the presence of a KF, and by $14 \%$ if a second $\mathrm{LF}$ was present. NAA + BA also reduced seed number per fruit. Seed number in the KF averaged 3.4 in the absence of a LF and 2.8 in the presence of a LF. A more dramatic reduction was apparent in seed content of LF, from 4.4 (NTC) to 2.6 in the absence of the KF compared with 4.7 to 0.14 in the presence of a $\mathrm{KF}$ and from 5.5 (NTC) to 0.6 in the absence of the KF and in the presence of a second LF. Thus, the NAA + BA treatment at 10 to $12 \mathrm{~mm}$ KFD increased the number of multifruited spurs, thereby increasing the population of LF with low seed content. Such fruit are generally considered noncompetitive (Heinicke, 1920; Westwood et al., 1968) and develop into small fruit or abscise during June drop; however, we show that NAA + BA treatment improves their retention but not their capacity to fully develop.

The NAA + BA effect on fruit retention may be a direct auxin effect and that on fruit growth indirect, because developing seeds are critical for fruit growth (Dražeta et al., 2004). The low seed complement would be expected to reduce the sink strength of the fruit and also the supply of hormones necessary for fruit retention and growth. The high incidence of small fruit induced by the Promalin (at KB) + NAAm (at PF) treatment (Table 1) was in contrast to the response from NAA, but this may be related to overthinning and, thus, a reduction in the sensitive, lateral fruit population (Table 2). Similarly, few small fruit were produced when NAA was oversprayed with BA at the $6 \mathrm{~mm}$ KFD stage where overthinning also occurred (Table 3;
Fig. 3). Our data support the conclusion that NAA + BA did not inhibit cell enlargement in 'Delicious', because it had no effect on fruit growth when applied after cell division was completed (18 mm KFD; Fig. 3) in 'Delicious' (Blampied and Wilde, 1968). Our data also conclusively established that NAA + BA inhibition of fruit growth in 'Delicious' and 'Fuji' was not related to crop load. Crop load after treatments with NAA + BA was similar to or less than that after application of NAA or BA alone, but the NAA + BA treatment induced 2.5- to 5- fold more small fruit (Tables 1, 2, and 4; Figs. 1, 2, and 4).

The incidence of small fruit was increased by a broad range of BA to NAA ratios $(25: 15$ to $125: 15 \mathrm{mg} \cdot \mathrm{L}^{-1}$ ) in 'Delicious' and 'Fuji', but not in 'Elstar', 'Gala', 'Golden Delicious', and 'Jonagold' (Fig. 5; Table 5). The amount of small fruit formation in the small-fruited cultivars Elstar and Gala was significantly reduced and mean fruit weight was increased in all cultivars (Table 5). These data are consistent with reports on NAA + $\mathrm{BA}$ increasing fruit size in several additional cultivars (Basak, 2006; Bukovac et al., 2007; Stopar and Lokar, 2003). The sensitivity of 'Delicious' and 'Fuji' to NAA + BA could have a genetic basis because 'Fuji' has 'Delicious' ('Delicious' $\times$ 'Rawls Jenet') as one of its parents. Interestingly, NAA + BA does not inhibit fruit growth in 'Empire', which was derived from 'McIntosh' growing next to 'Delicious'. Resolving the mode of action of NAA and BA on fruit growth would be significant for understanding and regulating cropping in apple.

The possibility that the NAA + BA inhibition of fruit growth may be related to an effect on photosynthesis merits comment NAA has been reported to depress $\mathrm{CO}_{2}$ assimilation (Stopar et al., 1997; Schumacher et al., 1993) and phloem transport of photoassimilates from apple leaves (Schneider, 1978). $\mathrm{CO}_{2}$ assimilation was significantly depressed by NAA in apple leaves of 'Delicious' and 'Empire'; BA was without effect. However, when the combination of NAA + BA was applied, BA overcame the NAAinduced inhibition of $\mathrm{CO}_{2}$ fixation in 'Empire', but only partially, and in a second year failed to reduce the NAA effect in 'Delicious' (Stopar et al., 1997). In contrast, BA enhanced leaf $\mathrm{CO}_{2}$ fixation and transport to developing fruit in citrus (Mauk et al., 1986). Direct evidence is not available suggesting enhanced partitioning of photoassimilates to apple fruit. Although these data provide some evidence for involvement of NAA and BA in carbon fixation in apple leaves, conclusive data are needed to couple these observations to fruit growth.

\section{Literature Cited}

Basak, A. 2006. The effect of ethephon, NAA and BA, used separately or jointly, on the efficiency of thinning in apple trees cultivars Jonagold, Golden Delicious and Elstar. Proc. Plant Growth Reg. Soc. Amer. 33:144-150.

Black, B.L., M.J. Bukovac, and J. Hull. 1995. Effect of spray volume and time of NAA application on fruit size and cropping of Redchief 'Delicious' apple. Sci. Hort. 64: 253-264.

Black, B.L., M.J. Bukovac, and M. Stopar. 2000. Intraspur fruit competition and position influence fruit size at harvest and response to chemical thinning agents in spur-type 'Delicious' apple. Acta Hort. 527:119-125.

Blampied, C.D. and H. Wilde. 1968. A study of the cells in the outer flesh of developing McIntosh apple fruit. Bot. Gaz. 129:173-183.

Bound, S.A., K.M. Jones, T.B. Koen, M.J. Oakford, M.H. Barrett, and N.E. Stone. 1991. The interaction of Cytolin and NAA on cropping red 'Delicious' apple. J. Hort. Sci. 66:559-567.

Bukovac, M.J., B.L. Black, and J. Hull. 1995. Interaction of NAA with Accel and Promalin on fruit size in 'Delicious' and 'Empire' apples. HortScience 30:765 (abstr.).

Bukovac, M.J., P. Sabbatini, P.G. Schwallier, and M. Schroeder. 2007. Characterizing the interaction between NAA and BA on fruit growth in different apple cultivars. HortScience 42:907 (abstr.).

Bukovac, M.J., M. Schroeder, and G. Noga. 2000. Effects of fruit thinning sprays of NAA and BA on cropping 'Elstar' and 'Gloster' apples. Acta Hort. 514:91-98.

Davidson, J.H., O.H. Hammer, C.A. Reimer, and W.C. Dutton. 1945. Thinning apples with the sodium salt of naphthylacetic acid. Mich. Agr. Expt. Quart. Bul. 27:352-356.

Dennis, F.G., Jr. 2000. The history of fruit thinning. Plant Growth Reg. 31:1-16.

Dražeta, L., A. Lang, A.J. Hall, R.K. Volz, and P.A. Jameson. 2004. Modeling the influence of seed set on fruit shape in apple. J. Hort. Sci. Biotechnol. 79:241-245.

Elfving, D.C. and R.A. Cline. 1993. Benzyladenine and other chemicals for thinning 'Empire' apple trees. J. Amer. Soc. Hort. Sci. 118:593-598.

Ferree, D. 1996. Performance of benzyladenine as a chemical thinner on eight apple cultivars. J. Tree Fruit Prod. 1:33-50.

Flaishman, M.A., A. Shargal, L. Shlizerman, R.A. Stern, S. Lev-Yadun, and G. Grafi. 2005. The synthetic cytokinins CPPU and TDZ prolong the phase of cell division in developing pear (Pyrus communis L.) fruit. Acta Hort. 636:151157.

Greene, D.W. 1993. A review of the use of benzyladenine (BA) as a thinner for apples. Acta Hort. 329:231-236.

Greene, D.W. and W.R. Autio. 1994. Combination sprays with benzyladenine to chemically thin spur type 'Delicious' apples. HortScience 28:887-890

Greene, D.W., W.R. Autio, J.A. Erf, and Z.Y. Mao. 1992. Mode of action of benzyladenine when used as a chemical thinner on apples. J. Amer. Soc. Hort. Sci. 117:775-779.

Greene, D.W., W.R. Autio, and P. Miller. 1990. Thinning activity of benzyladenine on several apple cultivars. J. Amer. Soc. Hort. 115:394-400.

Greenhalgh, W.J., G.L. Godley, and R. Menzies. 1977. Studies of fruit shape in apples: Response to gibberellin and cytokinin sprays. Aust. J. Expt. Agr. Anim. Husb. 17:505-509.

Heinicke, A.J. 1920. The seed content and position of the fruit as factors influencing stippen in apples. Proc. Amer. Soc. Hort. Sci. 17: 227-232.

Hoffman, M.B., L.J. Edgerton, and E.G. Fisher. 1955. Comparisons of naphthaleneacetic acid and naphthaleneacetamide for thinning apples. Proc. Amer. Soc. Hort. Sci. 49:37-41. 
Horgan, R. 1984. Cytokinins, p. 53-75. In: Wilkins, M.B. (ed.). Advanced plant physiology. Pitman Publishing Inc., Marshfield, MA.

Letham, D.S. 1963. Zeatin, a factor inducing cell division from Zea mays. Life Sci. 8:569-573.

Letham, D.S. 1968. Regulation of cell division in plant tissue. I. Inhibitors and stimulants of cell division in developing fruits: Their properties and activity in relation to the cell division period. N.Z. J. Bot. 1:336-350.

Letham, D.S. and M.W. Williams. 1969. Regulation of cell division in plant tissue VIII. The cytokinins of the apple. Physiol. Plant. 22:925936.

Luckwill, L.C. 1953. Studies of fruit development in relation to plant hormones. II. The effect of naphthalene acetic acid on fruit set and fruit development in apples. J. Hort. Sci. 28: $25-40$.

Luckwill, L.C. and C.P. Lloyd-Jones. 1962. The absorption, translocation and metabolism of 1naphthaleneacetic acid applied to apple leaves. J. Hort. Sci. 37:190-206.

Marsh, H.V., F.W. Southwick, and W.D. Weeks. 1960. The influence of chemical thinners on fruit set and size, seed development and preharvest drop of apples. Proc. Amer. Soc. Hort. Sci. 75:5-21.

Mauk, C.S., M.G. Bausher, and G. Yelenosky. 1986. Influence of growth regulator treatments on dry matter production, fruit abscission and 14C-assimilate partitioning. J. Plant Growth Reg. 5:111-120.
Miller, C.O., F. Skoog, F.S. Okamura, M.H. von Saltza, and F.M. Strong. 1956. Isolation, structure and synthesis of kinetin, a substance promoting cell division. J. Amer. Chem. Soc. 78:1345-1350.

Miller, C.O., F. Skoog, M.H. von Saltza, and F.M. Strong. 1955. Kinetin, a cell division factor from deoxyribonucleic acid. J. Amer. Chem. Soc. 77:1329.

Miller, P. 1985. Apple thinning in Australia. Horticultural Research Institute, Knoxfield, Victoria Dept. Agr. Rural Affairs. Ext. Bul. p. 1-36.

Schneider, G.W. 1978. Abscission mechanism studies with apple fruitlets. J. Amer. Soc. Hort. Sci. 103:455-458.

Skoog, F. and C.O. Miller. 1957. Chemical regulation of growth and organ formation in plant tissue cultured in vitro. Symp. Soc. Exp. Biol. Med. 11:118-131.

Southwick, F.W., W.A. Weeks, E. Sawada, and J.F. Anderson. 1962. The influence of chemical thinner and seeds on the growth rate of apples. Proc. Amer. Soc. Hort. Sci. 80:33-42.

Stopar, M., B.L. Black, and M.J. Bukovac. 1997. The effect of NAA and BA on carbon dioxide assimilation by shoot leaves of spur-type 'Delicious' and 'Empire' apple trees. J. Amer. Soc. Hort. Sci. 122:837-840.

Stopar, M. and V. Lokar. 2003. The effect of ethephon, NAA, BA, and their combination on thinning intensity of 'Summered' apples. J. Central European Agr. 4:399-403.
Stover, E., M. Fargione, R. Risio, X. Yang, and T. Robinson. 2001. Fruit weight, crop load, and return bloom of 'Empire' apple following thinning with 6-benzyladenine and NAA at several physiological stages. HortScience 36:1077-1081.

Wertheim, S.J. 2000. Developments in the chemical thinning of apple and pear. Plant Growth Reg. 31:85-100.

Westwood, M.N. and L.P. Batjer. 1960. Effects of the environment and chemical additives on absorption of naphthaleneacetic acid by apple leaves. Proc. Amer. Soc. Hort. Sci. 76:16-29.

Westwood, M.N., L.P. Batjer, and H.D. Billingsley. 1968. Cell size, cell number and fruit density of apples as related to fruit size, position in cluster and thinning method. Proc. Amer. Soc. Hort. Sci. 91:51-62.

Williams, M.W. 1979. Chemical thinning of apples. Hort. Rev. (Amer. Soc. Hort. Sci.) $1: 270-300$.

Williams, M.W. and E.A. Stahly. 1960. Effect of cytokinins and gibberellins on shape of Delicious apple fruits. Proc. Amer. Soc. Hort. Sci. 94:17-18.

Wise, J.C., L.J. Gut, R. Isaacs, A.M.C. Schilder, G.W. Sundin, B. Zandstra, R. Beaudry, and G. Lang. 2007. 2007 Michigan fruit management guide. Mich. State Univ. Ext. Bul. E-154: $162-165$.

Wismer, P.T., J.T.A. Proctor, and D.C. Elfving. 1995. Benzyladenine affects cell division and cell size during apple fruit thinning. J. Amer. Soc. Hort. Sci. 120:802-807. 